Debra Harwood is an academic and early childhood education scholar at Brock University, Canada. Debra's research is situated within a framework of challenging the social, political, cultural, and historical forces that have shaped central ideas such as care, professionalism, child agency, place, and intra-active pedagogy. Her most recent project involves a study of young children's entanglements within a forest, specifically examining how relationships with the more-than-human world might foster ways of being that support a more sustainable planet.

\title{
The Blue Car in the Forest: Exploring Children's Experiences of Sustainability in a Canadian Forest
}

\author{
We help nature grow \\ Deer, blue jay, rabbit or mouse \\ With food and tools in tow \\ We clean, feed, and build a house. \\ Because if it dies it can never grow. \\ So, no putting garbage anywhere, \\ Animals eat the garbage on the ground. \\ Clean water, land and air, \\ Animals die when garbage is found. \\ Please be aware! \\ (excerpt of poem by children in the Nature Program research)
}

\section{INTRODUCTION}

Early childhood has long been recognized as a period of a child's life where the foundations for thinking, learning, and being are shaped, including their relationships to others and a sustainable world (Sameulsson \& Kaga, 2008; Sameulsson \& Park, 2017). Although a universal definition does not exist, sustainability is generally considered as the interconnection of the social, political, environmental, and economical facets that underpin a sustainable world (UNESCO, 2007). Broadly speaking, early childhood for sustainability (ECEfS) is about "learning to think and act in ways that will safeguard the future well-being of people and the planet" (Ministry of Education New Zealand, 2015).

ECEfS can help educators to "highlight the complex interrelationships between the social, economic, political, and environmental dimensions over time" (Elliott, 2017, p. 299). This interrelationship emphasizes relationships, equity, social/political justice, and fairness amongst and between the human 
and more-than-human world ${ }^{1}$ (Davis, 2015). The Earth Charter (2012) represents this interrelationship to define sustainability as interrelated pillars and proposes specific principles toward achieving a sustainable planet; respect and care for the community of life, ecological integrity, social, political and economic justice, democracy, nonviolence and peace.

Undoubtedly, children 'bear the brunt' of an unsustainable world and will continue to do so in the future (UNICEF, 2014). Poverty, lack of access to clean water and food, pollution, increased industrialization, and over-crowding critically impact children, particularly those living in poverty (Davis, 2015). However, children should also be recognized for their ability and right to contribute to sustainable solutions, particularly at local levels. By contributing locally, children also come to understand and influence larger global systems (Elliott, 2017). Early childhood education has a longstanding interest in fostering a sustainable society (Pramling Samuelsson, 2011), demanding children be viewed as competent, capable agents of change and stakeholders of a sustainable future (Gothenburg Environment Centre, 2010). This paper views children as competent, and capable contributors to these understandings. They can show us how to live relationally with those around us (both human and more-than-human).

Teaching young children about sustainability is not new. Korea and Australia's early childhood curriculum frameworks, for example, include a clear focus on sustainability (Inoue, O'Gorman, Davis, \& $\mathrm{Ji}$, 2017) while other countries like Sweden, contain more nuanced goals that focus on environmental, social, political, and economic dimensions of sustainability (Engdahl \& Ärlemalm-Hagsér, 2014). Elliott (2017) discusses the four historical pillars that have shaped the discourses of sustainability and early childhood education, namely "the child in nature; revisioning images of the child; changing outdoor play spaces; and environmental education/education for sustainability" (p. 296). She posits that these historical pillars have led to misconceptions and assumptions about sustainability such as, the need to protect young children from being over-burdened with global issues such as climate change. Elliott proposes that these discourses have worked to constrain pedagogies and limit research endeavours; often pitting nature advocates in opposition to sustainability scholars and educators. Gaps exist in definitions, concepts, policies, and approaches to education for sustainability. Both Davis (2009) and Elliott (2017) have been critical of these gaps and urgently call for synergies between new theoretical understandings and pedagogies. Holbrook (2009) underscores the importance of equipping children with interdisciplinary scientific knowledge and analytic capabilities, enabling them to participate in the big socio-scientific issues of today, such as global warming, pollution, and toxic waste disposal.

Engaging children in early childhood for sustainability (ECEfS) (Davis \& Elliott, 2014) means moving beyond protectionist ideas of children acting as stewards of the environment, notions that are criticized for "placing humans strictly outside the natural world of which they are a part of, and may thereby inadvertently perpetuate the very alienation it seeks to overcome" (Anderson, Comay, \& Chiarotto, 2017, p. 109). Elliott and Davis (2009) have stated, "there is possibly no greater concern impacting on the lives of young children than the state of the environment and the equitable and sustainable use of its resources" (p. 66). But introducing such complex ideas of climate change, mass consumption, and unsustainable practices with children as young as 3 to 5 years of age can be daunting, expressly given the often-prevailing presumption of childhood as a time of innocence (Elliott \& Davis, 2009). Others have also noted the gap in research focusing on how to teach children about sustainability, particularly given the predominance of play-based pedagogical approaches (Edwards \& Cutter-Mackenzie, 2013).

Learning for sustainability requires both experiences and socio-technoscientific conceptual understandings (Holbrook, 2009; Mackey, 2012; Vaealiki \& Mackey, 2008); concept learning that may

\footnotetext{
1 Aligned with Lynch and Mannion's (2016) use of the term more-than-human, as a researcher I paid attention "to processes and materials beyond the human" (p. 332), including matter such as sticks, rocks, water, insects, plastics, and an abandoned blue car in the forest; noting the relevance of the intra-actions between/among/with children and animate/inanimate matter.
} 
not be evoked for young children unless provoked by an educator. Young children can understand, contribute ideas, and take action related to complex ideas with the support of knowledgeable educators (Mackey, 2012). Boyd's (2016) case study helps highlight how children's understandings and educators' pedagogies can be impacted by authentic sustainability projects that are meaningful. By adapting playhouses with sustainable components (e.g., installing solar panels), Boyd found ways of combining play-based pedagogies with sustainability concepts, promoting both the children and educators' understandings and actions. Despite these promising insights, shifts toward more critical and transformative pedagogies that foster opportunities to explore sustainability issues with young children remain vital (Robinson \& Vaealiki, 2010).

How do situated and repeated experiences immersed in a natural forest provoke opportunities for children to engage with sustainability? As Davis $(2009,2015)$ points out, children immersed in nature learn about nature, but is that enough? How do we challenge the 'nature by default' pedagogies that appear pervasive (Elliott \& Young, 2015) and disrupt the constrained views of sustainability of educators (Cincera et al., 2017)? Researchers have focused on the educators' understandings and practices with sustainability; how sustainability is understood and experienced by children is not clear. In this paper, I highlight various data vignettes from a qualitative study of a nature preschool program involving eight children and their two nature teachers immersed in the woods of a university campus in Ontario, Canada. By storying, their critical engagements with an abandoned blue car in the woods over the course of a year, I highlight how children's thinking, relating, and acting on sustainability are entwined with their repeated more-than-human encounters.

\section{CHALLENGING NAIVETÉ - CHILD AND NATURE ASSUMPTIONS}

Some critics caution about the romanticism of children in nature as idyllic and innocent, and the assumption that humans are alienated from nature (Malone, 2016). As the poem at the start of the paper helps to demonstrate, children of the Anthropocene epoch understand the entanglements of this world and the impacts of environmental issues on themselves and the more-than-human inhabitants. The Anthropocene, a term greatly debated in the literature (Haraway et al., 2015), is viewed as the current geological period during which human activity has been the dominant influence on the environment that can be traced in earth strata (Lewis \& Maslin, 2015). It is often related to as a signal for an uncertain ecological future precipitated by humankind's use of and exploitation of natural resources. The term Anthropocene itself is problematic given the etymology of the word (-anthropo meaning 'human' and -cene meaning 'new') and the risk of further validating human exceptionalism is a common theme within the debates (Instone \& Taylor, 2015; Taylor, 2017). The discipline of early childhood education is often critiqued for its Anthropocentric focus, perhaps resultant from this long history of romantic entanglements of child and nature (e.g., Rousseau, Fröebel) (Duhn, 2012). The central yet, currently unrealized role of early childhood education in creating sustainable futures has been overlooked (Elliot \& Davis, 2009).

Despite educators' best intentions, outdoor pedagogies can often be described as 'nature by default' (Elliott \& Young, 2015) where children playing in nature is a familiar and comfortable activity (Elliott, 2016). What is often considered as teaching for sustainability by some educators involves planting, gardening, recycling or more common 'green centric' practices (Ernst, 2015, p. 163). Notwithstanding that these practices are an important contribution, often they reinforce idealized notions of the child and further constrain children's roles as decision-makers in communities that they are a part of. Elliott and Young (2105) raise the important question, "are evocative images of children playing in nature and the dominance of nature experiences in early childhood curriculum enough to promote a sustainable future" (p. 57)?

A critical examination of 'nature by default' pedagogies and the romanticized notion of the innocent child is clearly needed for sustainability to gain momentum within curricula and pedagogies for young children. Overwhelmingly, much of the research conducted thus far has focused on children's connection to nature, and ontological and epistemological assumptions underpinning the research have yet 
to be examined (Somerville \& Williams, 2015). Nature is often conceived of as something that exists outside of humans, pure and untouched while culture is rationalized, civilized, and human centric (Cielemęcka, 2018). This polarization fails to account for the entanglements and complexities of the human/more-than-human world and more speculative and experimental ways of thinking about sustainability are called for (Cielemęcka, 2018; Heise, 2016). Some scholars have critiqued the nature movement for its naivete and lack of critical examination of the philosophical underpinnings of curricula and educators' teaching practices (Leather, 2018; Somerville \& Williams, 2015). Moreover, this naiveté has limited and constrained educators and children's explorations of complex ethical issues inherent in global sustainability goals (Davis \& Elliott, 2014). Despite the growth in early ECEfS research of the last decade (Davis, 2009; Somerville \& Williams, 2015), a clear focus on sustainability has yet to materialize consistently within the various early childhood education (or kindergarten curricula) frameworks found throughout Canada.

\section{THEORETICAL FRAMING}

In this paper, I explore different ways of thinking about young children and learning for sustainability by using a post-humanism conceptual framing. What might be possible when educators (and researchers) make space for the entanglements between the human and more-than-human world, and recognize the agency of all matter within the spaces and places where children, teachers, and the world coexist (Barad, 2007; Haraway, 2008; Somerville, 2010; Taylor \& Giugni, 2012). Clearly, if we experience and understand 'others' (including the non-human world), respect the mutuality, connectedness, and interdependence of all matter, we can learn to 'act together' for a sustainable world (Elliott, 2017). As a starting point, I use post-humanism theory to challenge the centralism of humans within ECEfS curriculum by refocusing on the inter-dependence between people and the more-thanhuman world. What seems significant within this theoretical framing is the emphasis on relationality, mutual becomings, and entanglement of all agential entities (Vladimirova \& Rautio, 2019). Ritchie (2017) writes, "integral to the achievement of living sustainability within our finite planet is the cultivation of empathy and compassion for others, including our more-than-human cohabitants, and for the planet itself, its biosphere and atmosphere" (p. 294).

Young children can develop a heightened awareness and thoughtfulness toward the environment, learning to act in responsive ways with more-than-human others. Specifically, intentional pedagogical approaches that are enacted to carefully attend to all matter and afford children and educators ample time to notice and listen are important for teaching and learning for sustainability (Nxumalo, 2018; Pineda, 2018). Elliott (2017) advocates for multiple "avenues to explore beyond play in nature and, ethically, educators can no longer afford to comfortably just 'do' nature without question” (p. 302). Blaise and her colleagues (2016) also encourage pedagogies that are considerate of the morethan-human world recognizing "we are entangled with all sorts of forces, elements, and species beyond ourselves" (p. 9). Yet, much of the environmental and ECEfS research conducted thus far is rooted in humanistic universalisms, largely oblivious of theoretical ideas that help to disrupt human exceptionalism (Nxumalo \& Cedillo, 2017). Particularly relevant, a post-humanist theoretical framing offers a critique of human exceptionalism and the false notion that humans are sole conveyors of agency (Latour, 2004; Plumwood, 2002). Posthumanism theory helps in examining the intra-actions of children and more-than-human others, recognizing the agency of all matter within the 'common world' (Haraway, 2008; Tsing, 2015). By engaging in 'common worlds' thinking, we can recognize that humans are entangled and enmeshed. Child/nature/matter are not separate entities, rather the multiple agentic forces "wrap around one another" (Ingold, 2013, p. 105) in processes of mutual becoming. Hackett and Rautio (2019) explain that "children (or humans in general) do not experience themselves as neatly outlined units but as moving and continually responding, bodies in correspondence with the world" (p. 1022); meaning-making processes from body/matter "experiences of alterity" (p. 1022). 
The most pervasive body of research on sustainability that utilizes a post-humanist framework lens comes from the work of Jennie Ritchie and Iris Duhn and their colleagues in New Zealand. These researchers conducted a two-year qualitative study focused on global issues of ecological sustainability within 10 early childhood education centers throughout New Zealand (Ritchie, Duhn, Rau, \& Alberts, 2010). In their final research report, the authors describe their methodology as one that combines aspects of narrative, kaupapa Māori, critical indigenous and ethnographic methodologies. Drawing upon the Māori conceptualization of relationality and Noddings (2005) ethics of care as global citizens, Ritchie (2012) highlights the role of early childhood education as foundational to addressing the complex issues of sustainability. Yet, they also found that educators' comfort levels with exploring ideas of ecological sustainability or global issues with young children were varied, and notions of the centre as a 'special' place and the educator as 'protector' were disrupted (Duhn, 2012). Perhaps, the intersection of educators' 'pedagogies of place' as encompassing both the local and global (Duhn, 2012) need time and support to emerge. Clearly, this body of research by Ritchie and her colleagues established the advantages of embracing theoretical dispositions that provide a counter-narrative to narrowly defined discourses of learning, environmentalism, and inevitable environmental doom. In this sense, ideas of reciprocity and living relationally with an ethic of care for the human and morethan-human world, offers hope and a way ahead for achieving a sustainable planet.

Children are enmeshed with the world around them and pedagogies need to provide access to ideas and ways of learning to help children navigate and ethically respond to the complexities of the world (Nxumalo, 2018). Like others (Robinson \& Vaealiki, 2010), I foresee children and educators involved in contextualized issues related to sustainability that have personal meaning and relevancy, rather than being burdened with solving all of the world's environmental issues. But this shift does require new ways of thinking about children, education, and teaching. Similar to the concept of sustainability itself (Elliott, 2017), children's worlds are messy, entangled, complex, and multidimensional. The research project discussed in this paper occurred within a nature program on a university campus woodland in Canada, and challenges notions of sustainability that are rooted in naïve notions of the child in nature. By expanding views of agency and granting recognition of the entanglement of child/ matter, shifts within learning for sustainability can be achieved.

\section{METHOD AND ANALYSIS}

The Ontario based nature program is one of the services offered within a university campus centre ${ }^{2}$. The oldest group of eight children from the centre participate in the nature program each year, involving twice weekly immersive experiences in the local woods from September to June. The nature program follows an inquiry pedagogical model (Anderson et al., 2017), where place-based approaches (Wattchow \& Brown, 2011) and learning to live relationally with others of the 'common world' figure prominently in the approach (Taylor \& Pacini-Ketchabaw, 2015).

The nature program and the three-year research study were undertaken by the collaborative efforts of both the researcher (author) and the centre. In this paper, I focus on the data collected from the third year of the study, recognizing fully that children's experiences and educators' pedagogies have transformed over time. Moreover, the methodological approaches educed by this long-term foray into the woods are fluid as the goal of post-era research is to unsettle the usual foci and allow for something new to emerge (Harwood \& Collier, 2017; Harwood \& Collier, 2019).

Originally conceived of as an ethnographic informed case study, a methodological approach that combines principles of ethnography (LeCompte \& Preissle, 1993) with case study (Stake, 2008), the design was participatory, exploratory, naturalistic, multimodal, relational, visual/sensual, and interpretive (Clark, 2010; Denzin \& Lincoln, 2011; Holland, Renold, Ross, \& Hillman, 2010; Hultman \& Lenz Taguchi, 2010; Mitchell, 2011; Pink, 2001; 2015; Rose, 2012). Retrospectively, the methodologies are

\footnotetext{
2 The centre offers multiple programs for children from birth to 5 years of age. The centre's name has been intentionally omitted to ensure the confidentiality of the participants.
} 
better described as 'messy' (Rautio, 2013), and like others I paid attention to the 'vibrant materialities' of children's worlds as a valid research pursuit (Malone, 2016; Somerville, 2017). The overarching research question of the entire study focused on identifying and exploring the intra-active and improvisational entanglements in a forest program that offered opportunities for play and learning for preschool age children. The sub-question guiding the discussion in this paper concentrated on examining the ways in which sustainability in outdoor play spaces are enacted, particularly focusing on what sustainability opportunities are evoked for the children to know, decide, and act within their more-than-human entanglements in the outdoors. The goal was to better understand how nature encounters might offer opportunities to engage children and educators in thinking about and acting upon some of the big ideas of sustainability, such as climate change, pollution, mass consumption, environmental degradation, and unsustainable practices. The data collection tools used in the study included participant observation, interviews, visual methods (photo/videos), and GoPro cameras worn by the children; tools that helped to challenge the 'anthropocentric' gaze that is well ingrained within early childhood educational research (Harwood \& Collier, 2019).

Relying on and combining multiple processes in this study was somewhat of a novel approach, and when combined the methods afforded a lens to pay attention to the mundane, the everyday, the multiple layers of complex encounters between children and the more-than-human world. The paper is a small part of a much larger three year study, whereby the vignettes of data related to the blue car were analyzed to illustrate the ways in which sustainability learning was enacted, fully appreciating the messy, mixed-up entanglement of the human and more-than-human world (Barad, 2007).

\section{THE CHILDREN, EDUCATORS, FOREST, AND BLUE CAR}

The participants of the third year of study included the children, educators, forest, the blue car, me, a student researcher, and many 'others' we encountered in the woods. Susan and Rachel (pseudonyms), the two nature educators, had varied levels of experience in the field of early childhood education (20 and 3 years; respectively), while Susan has taught in woods for the last three years, Rachel was new to the nature program. Both educators described a personal and professional history of experiences related to teaching outdoors and emphasized the importance of outdoor experiences for children's development as well as fostering children's empathetic relations with the world. In Rachel's survey response she stated the view:

I wish for this group to be leaders in their generation for sustainability of our earth, to be capable, confident and curious. Be willing to take risks, gain problem solving skills, be empathetic towards others and work in a cooperative and collaborative environment.

Notwithstanding, the educators are an integral aspect of this research project, here in this paper I focus on the children, nature, and the blue car as important 'performative agents' (Barad, 2003). Barad writes, "The world is an ongoing open process of mattering through which "mattering" itself acquires meaning and form in the realization of different agential possibilities" (p. 817). Thus, the various aspects of our world become intelligible to one another through processes of intra-activity (Ingold, 2013). The blue car is representative of the diverse and multiple materials within the forest context, illustrative of child-matter relations that are messy, entangled, complex, and intra-active (Taylor \& Pacini-Ketchabaw, 2015).

The five preschool aged girls and three boys that participated in the third year were between 3 and 4 years of age. The children had varied levels of outdoor experiences as reported by their parents. All the children were familiar with the nature school, given each have attended the childcare centre for several years (often since infancy). Additionally, they have observed former groups of preschoolers trudge out to the forest in the preceding two years and each child had attended a day in the forest as a special guest prior to attending the nature program. The forest, where the children play is part of a unique biosphere. The geological history is estimated to be 430 to 450 million years, while the 
human history represents approximately 10,000 years of entanglement of the forest and the lives of the Anishinaabe and Haudenosaunee Indigenous peoples. The uniqueness of the forest is evident in both the human and more-than-human history. Today, a university campus is co-located amongst the diverse varieties of trees, mammals, birds, plants, insects, and landscape.

The participating blue car, a 1958 Renault Dauphine, was originally made in France and marketed as an economical car for the 'masses' (Roberts, 2007). Ultimately the Dauphine would garner the reputation as one of the worst 50 cars of all time, particularly within North America with the car's exposure to harsh winters, fueling one critic to state, "if you stood beside it, you could actually hear it rusting" (Neil, 2007). Despite this, the blue car is a central agent of our study, acting upon the children in ways that were most likely unimagined by its original manufacturer. The car sits nestled amongst trees, brush, weeds, spider webs, flowers, pine needles, and more. The car has also been incorporated within the community's mountain biking trail system, and a wooden plank serves as a bridge over parts of the car for cyclists to traverse (Figure 1). The blue car was discovered by the children early in the third year on one of their many exploratory hikes, quickly becoming a centre piece for their multiple experiences in the woods. The blue car was a co-present nonhuman alongside the children, acting as a physical landmark, a wonderful discovery, a play space for experimenting, a topic of conversation, a model to show others who visited the woods with the children, and so much more.

We visited the blue car often throughout the year as the children's inquiries shifted from 'how did it (the car) get here', to complex issues related to 'what is happening to the car' to even more complex ethical complexities that focus on ideas of fairness, environmental responsibility, and reciprocity. What follows are several vignettes chosen to highlight the emerging sustainability related themes from the situated analysis of the fieldwork data (Pink, 2015). Analysis was a continual and flexible process of reflexivity, exploring moments of the fieldwork and the multiple connections between matter and children. Three themes emerged: what children know and define as sustainability; deciding to be present with the car in the forest; and acting to educate others toward a sustainable world. Each theme is discussed below to highlight the ways in which children's knowledge and actions are coconstructed with human and more-than-human others of the forest.

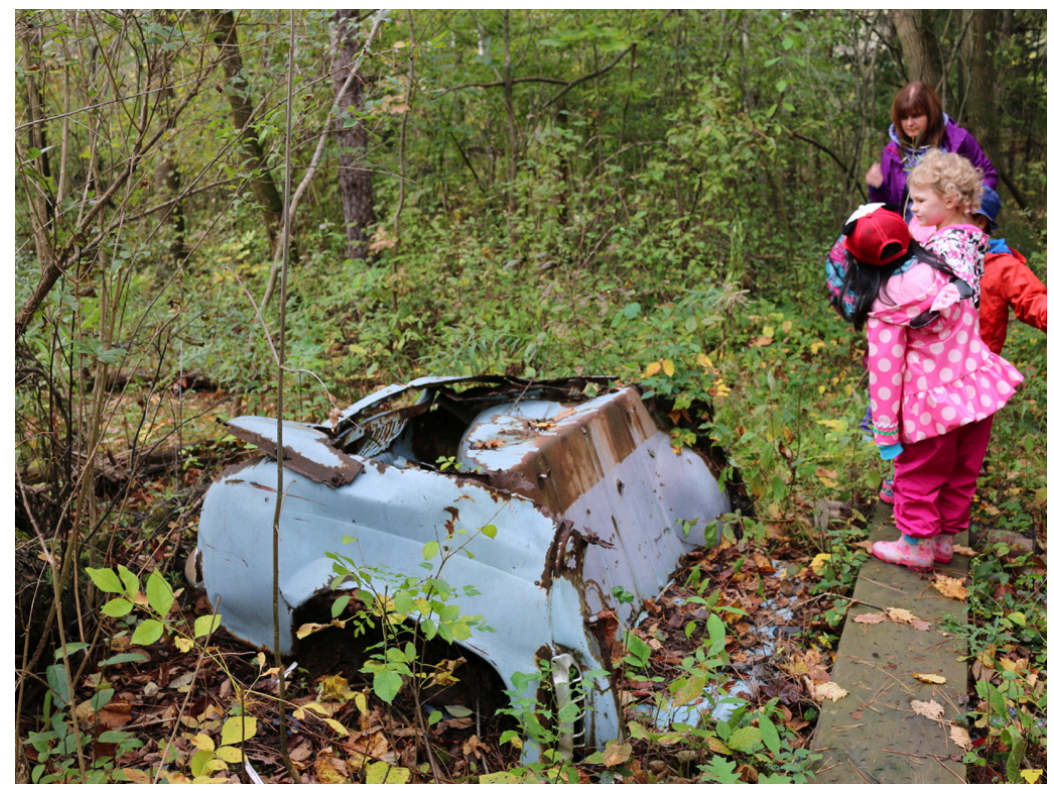

Figure 1: The blue car 


\section{KNOW: CHILDREN DEFINE SUSTAINABILITY}

Sustainability was a new concept for the children, nature educators, and the centre. In fact, the curriculum framework that guides these educators does not make any reference to sustainability, outdoor learning, or environmentalism (Best Start Expert Panel on Early Learning, 2007). Thus, one of the early tasks of the third year involved engaging the educators in reading materials on sustainability provided by the researcher (e.g., Elliott, 2019).

Correspondingly, the children's understanding of sustainability emerged slowly throughout the third year. During the first visit to the blue car in the autumn, the children spent time exploring and labelling the various component parts that were visible, first focusing on identifying whether or not this was indeed a car. The children also fixated on the rust, asking the educator to explain what it was and how it formed. The concept of oxidization and leaching was explored with follow up activities conducted in the classroom, introducing the children to the complex issues of chemical processes and soil pollution. However, the children were primarily concerned with the presence of the car in their 'natural' woods.

Should cars be in the forest, the educator, Susan asks. The children all agree no. The educator asks, then what should happen to old cars? There is an interesting discussion about where old cars belong, garage, on the road, etc. The educator provokes the children, by stating 'can I put my old car in our forest school'. They state no! Danika says, 'no you can't it will be a mess'! Susan asks again, 'should cars be in the forest'? The children chime no. Danika says, "no they should be in the garage". Susan probes further "what if they are old and broken, then where should they be". Neil offers that "old cars can be with workers who make them new again". Susan affirms for the children that old cars can be recycled.

$\sim$ Video Transcription, October in the Forest

Although recycling is something these children were familiar with, the idea of car recycling was relatively new for most of the children. Later, the children and their educator follow up on this introductory concept by watching a video of car recycling operation in the classroom. Here, the car discovery and initial phase of exploring seemed to have served as a precursor for learning about/in/for the environment (Davis, 2015). Throughout the year, the children referred back to the car and their discoveries to think about their relationship and ethical responsibilities to the woods (i.e., learning for the environment). "The world doesn't like garbage" became a common catch phrase amongst the children and decision making often included weighing human concerns with those of the non-human inhabitants of the woods.

In the spring of the third year, the children were invited to the university library to talk about their explorations in the forest. The children's recorded and observed conversation helps to highlight the children's understanding of sustainability and the complexities of an entangled world.

The librarian asks, tell me about the blue car? One child explains how to find the blue car in the woods with a long explanation of following the dirt road, then the twisting, turning path, and so on. Other children chime in with their knowledge of how to get there. The children then go on to explain that it's not supposed to be in the woods and share some of their theories on how it got there (crash, dumped, parked in the spot then rusted). One child's comment that the animals, spiders, and plants now live in the car so it can't be moved. Susan begins to read a storybook (Bullard, 2011) to the children. She pauses frequently to ask the children for their ideas or understanding of different words in the text, like litter. Later, when the educator asks what the word sustainability means, Danika says it has something to do with garbage and cleaning the earth. Other children chime in to say it's about helping the earth. Susan explains that it is about both those ideas and about using things that might not hurt the earth. Neil states, Iike using the recycle', pointing to the recycle box directly in front of them. Susan agrees then says it is about making choices on how to live so no one, including animals gets hurt and repeats the examples from the book that they have already discussed (e.g., reusable lunch bags, sharing clothes and 
toys instead of buying new, water bottles, not using plastic baggies, reusable shopping baskets, refusing plastic); ideas the children have provided as examples of familiar practices at the child care centre and their homes...The children react with gasps to pictures in the book of burning and burying garbage. Susan asks the children their opinion on what should be done with garbage. The children are adamant about recycling, but Susan presses them to consider garbage that can't be recycled. Several children chime in that burning creates too much smoke and pollution, and there appears to be general agreement on burying garbage. Susan states, 'ok I'm going to bury my garbage in Neil's backyard'. Neil claims that this isn't fair or right. Danika cries out 'like the blue car buried in our forest'. An ethical type discussion follows focused on the fairness of burying garbage in anyone's backyard, town, or space. The children agree that burying and burning are both 'bad' and the discussion flows back to ideas of recycling, buying local, and buying less.

Observational Notes, April Library Visit

The children's sophisticated understanding of both the complexity of the blue car's entanglement in the forest and the concept of sustainability was evident in the library conversation. The teaching and learning that occurred about/in/for the environment had become more complex over the year of repeated visits to the car. The blue car was revered by the children, given its intricate and relational role in the children's forest lives, and the way in which it also supported animals, insects, and plant life. Although the children were quick to provide a list garbage they had found in the woods, and stated that garbage hurts animals, people, plants and the idea that garbage is 'not fair'; the blue car was exempt from this list shared with the librarian. The complexity of the issues related to sustainability were narrated by the children, such as the idea of waste management (i.e., where to bury trash or the hazards and ethics of burying versus burning trash). The blue car was both revered by the children and disconcerting when ideas of burning or burying garbage were discussed, again hinting at the complexities of learning for substantiality.

\section{DECIDING: BEING PRESENT WITH THE CAR IN THE FOREST}

The children's interest was fully captured by the blue car. They recognized the car as entangled with the forest and their own lives. Conversations about removing the car from the woods was often fraught with conflicting ideas and tension amongst the children. The car provoked the children to explore its various parts strewn about the forest, measuring, drawing, detailing, and hypothesizing about what they found (Figure 2). Over the months, sticks were gingerly pushed into the various holes, magnifying glasses were used to observe the spiders living in the compartments, trees, leaves, door handles, chips of paint, the feather laying nearby all invited the children to act in certain ways. They were curious but also careful with the car and its many inhabitants. With each visit, the children carefully returned car parts to their original spots in the forest, leaving the spiders and new growth sprouting up through the car undisturbed. The car was vibrant or an actant (Bennett, 2010) in the children's lives.

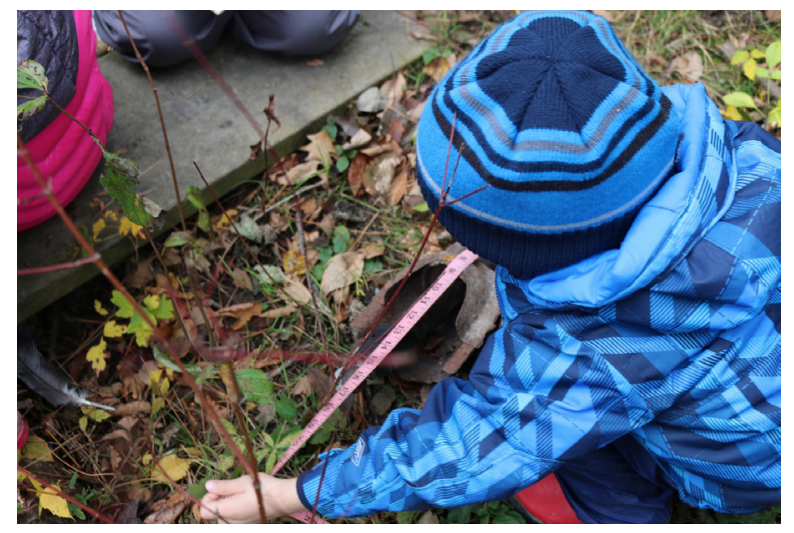

Figure 2: Measuring car parts 
The car was always present, provocative, sparking the children's imaginations and playful encounters (Figure 3).

Once we arrived at the car three girls Etta, Gina, and Mimi are seated where the former seats of the blue car are imagined having existed. Gina says, "Beep beep! We're going to Disneyland! Mimi responds, "No! We're going to M. Land because Disneyland is closed!" Gina retorts, "No wait! We're going to Hawaii!" Mimi agrees, "We're going surfing!" Gina says, "I've been surfing before, I know what that is!" Mimi stands up on the frame of the car, bending her knees, and states, "Look, see! I’m surfing!"

$\sim$ Transcription-January Playful Encounter

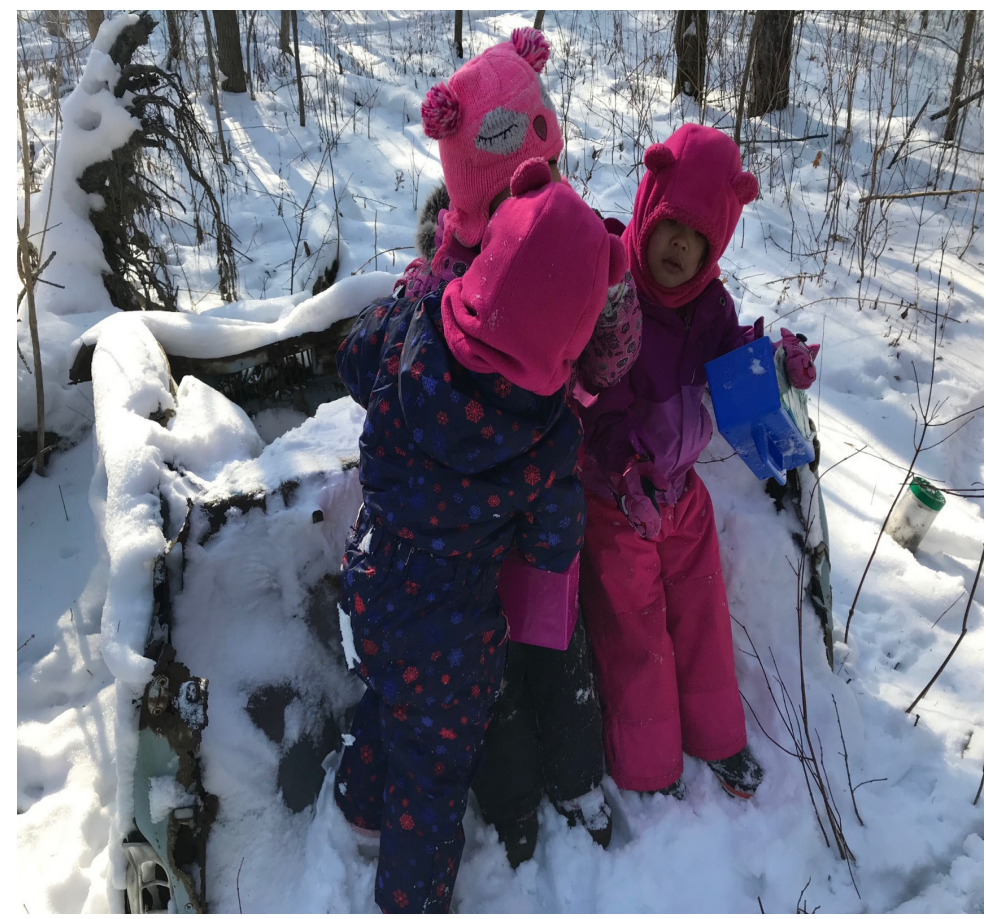

Figure 3: Playful encounters with the blue car

The car, forest, children are "entangled in thing and human, a space where both are vital to the production of the something created" (Thiel, 2015, p. 115), in this case serving as a provocation for thinking and acting differently in relation to a sustainable world. The blue car served as a prompt throughout the year for the children and educators to examine ideas of "mutuality, responsiveness, and interdependence" (Elliott, 2017, p. 311), the cornerstones of sustainability that evoke actions for change. The blue car was just one example of the multitude of human-non-human encounters in the woods that helped motivate the children's thinking and acting. The blue car served as an important connection to explore the complexity of children's enmeshed play lives in the forest, providing insight into how these moments might serve as a vital link between common worlds view and sustainability.

\section{ACTING: EDUCATING 'OTHERS'}

The children assumed the role of advocate and expressed interest in a plan to educate the other inhabitants of the campus (i.e., students, faculty, staff, visitors). As part of the children's inquiries and play in the third year of the study, they planned a display and 'protest' for the adults who share the 
university campus woodlands. Throughout the year, the children had documented and removed garbage from around the blue car and many other spots throughout the forest. The decision to share their collective ideas with the other human inhabitants of the campus became a clear focus, and the resulting display was entitled 'the sick earth'. The children's project culminated in a collective work of art, poem, information poster, and a letter to the adult students. The children's work was displayed in two of the libraries located on campus (Figure 4). The children shared a clear focus within the work on the ethics of acting responsibly towards others, naming those others as the non-human inhabitants of the forest.

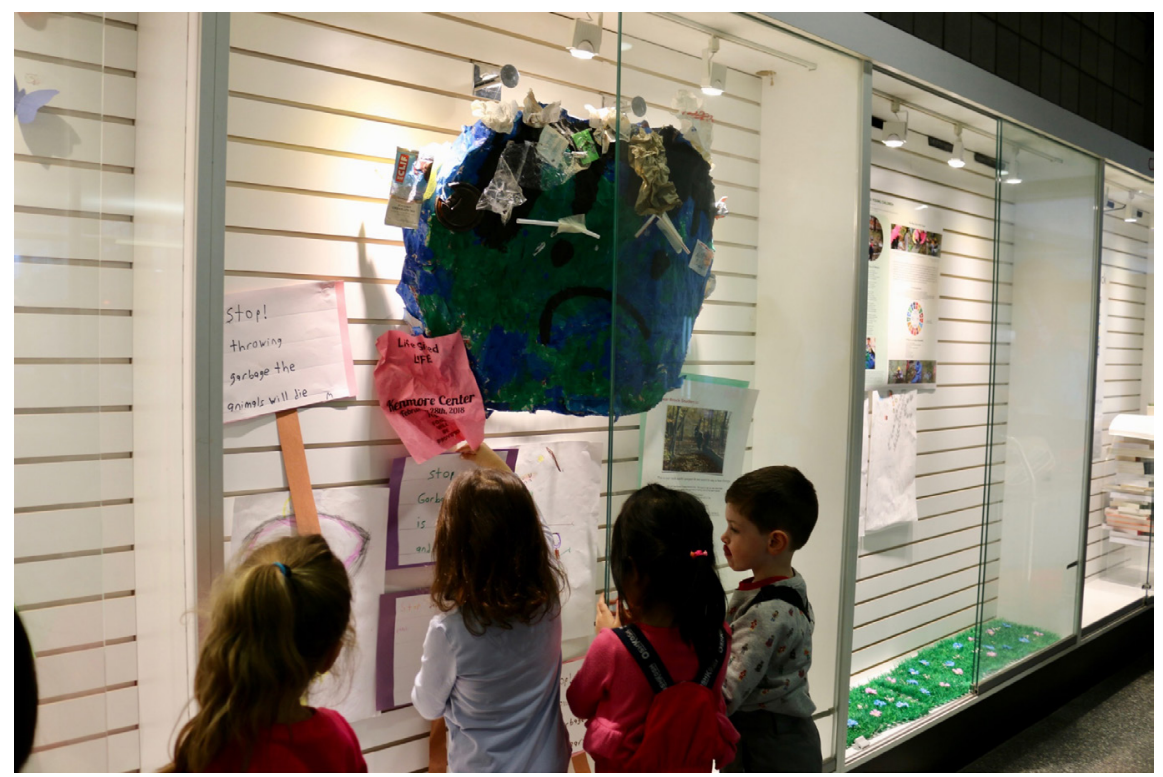

Figure 4: Acting for Sustainability

The children excitedly shared clear messages within the university display and balanced directives on their signage (e.g., "stop throwing garbage") with notes that demonstrated the need for human reciprocity and shared understanding with the more-than-human world (e.g., "animals will die"). Seemingly, the children had achieved their goal and perhaps new ripples of understanding emerged and the synergies needed for ECEfS clearly emerged. Countering the often-romanticized view of nature or 'nature-as default' pedagogies (Elliott \& Young, 2015; Leather, 2018; Somerville \& Williams, 2015), the children of this study experienced the woods as an entangled, messy, and complex world. They resisted ideas that polarized human and non-humans, rather for them all matter mattered. What seems clear is that children have a real role to play in challenging the thinking and perhaps actions of others in achieving sustainable communities.

\section{CONCLUDING DISCUSSION}

Vaealiki and Mackey's (2008) metaphor 'ripples of action' calls for a need to strengthen environmental competency of both children and educators within early childhood education (Holbrook, 2009). Vaealiki and Mackey advocate for paying attention to "children's thinking and questioning [as] a significant catalyst" (p. 8). Here, I extend that metaphor to include the importance of the ripple of attending to the entanglements, reciprocity, mutuality of the child and non-human world. The reciprocity within the child-non-human world also give rise to greater opportunities to explore children's thinking, relationships, and intra-actions about sustainability. The main finding of the study, that is the child positioned in relation to the blue car, opened up new ways of noticing these kindred intra- 
actions between human and more-than-human matter. The blue car has a 'role' in the woods as one of the (inanimate) more than-human-inhabitants, for better or worse. Even if the car has disturbed the biosphere of these woods, it is now part of the latest history of this place. These insights, even if slight and initial, gained through being present with place, and through multiple explorative, collaborative and environmental inquiries (Anderson et al., 2017; Wattchow \& Brown, 2011), empowered the children to empathize with the more-than-human inhabitants of the woods, including the blue car. The children's exemption of the car from the list of garbage, then is an informed decision. A decision that may elucidate and give expression to the deeper and intertwined connections between nature and culture.

By returning to the familiar over time, multiple occasions were provoked for "collective thinking in the presence of others [requiring us to] slow down, to be present enough to notice the multiple presence of others" (Instone \& Taylor, 2015, p. 137). Here, the children's concerns were intertwined with the more-than-human worlds interests, often spurring ways of both knowing and responding to the world that are less human-centric (Rooney, 2018). This small-scale study offers a glimpse into the possibilities that can emerge when we move beyond human-centric ways of thinking about sustainability. By countering the human/nature divide and continuing to recognize the entanglement of all matter (such as the child/blue car), the common world replete with both its beauty and vulnerabilities can become the shared responsibility of all, including young children.

\section{REFERENCES}

Anderson, D., Comay, J., \& Chiarotto, L. (2017). Natural curiosity: The importance of Indigenous perspectives in children's environmental inquiry (2nd ed.). Toronto, ON: University of Toronto.

Barad, K. (2003). Posthumanist performativity: Toward an understanding of how matter comes to matter. Signs, (3), 801.

Barad, K. (2007). Meeting the universe halfway: Quantum physics and the entanglement of matter and meaning. Durham, NC: Duke University Press.

Blaise, M., Hamm, C., \& Iorio, J. M. (2017). Modest witness(ing) and lively stories: Paying attention to matters of concern in early childhood. Pedagogy, Culture, \& Society, 25(1), 31-42. doi: 10.1080/14681366.2016.1208265

Bennett, J. (2010). Vibrant matter: A political ecology of things. Durham, NC: Duke University Press.

Best Start Expert Panel on Early Learning. (2007). Early learning for every child today: A framework for Ontario early childhood settings. Toronto, ON: Ministry of Children and Youth Services.

Boyd, W. (2016). Playing cool: The sustainable cool cubby. Australasian Journal of Early Childhood, 41(3), 29-37.

Bullard, L. (2011). Look out for litter. Minneapolis, MN: Cloverleaf Press.

Cielemęcka, O. (2018, April). Anthroposcenery: Imagining environmental futures with feminist environmental humanities. Presentation at Transdisciplinary Seminar Series in Sustainability, Brock University, St. Catharines, ON.

Cincera, J., Kroufek, R., Simonova, P., Broukalova, L., Broukal, V., \& Skalík, J. (2017). Eco-school in kindergartens: The effects, interpretation, and implementation of a pilot program. Environmental Education Research, 23(7), 919-936.

Clark, A. (2010). Young children as protagonists and the role of participatory, visual methods in engaging multiple perspectives. American Journal of Community Psychology, 46(1/2), 115-123.

Davis, J. (2009). Revealing the research "hole" of early childhood education for sustainability: a preliminary survey of the literature. Environmental Education Research, 15(2), 227-241. 
Davis, J. (Ed.). (2015). Young children and the environment: Early education for sustainability (2nd ed.). New York, NY: Cambridge University Press.

Davis, J., \& Elliott, S. (2014). Research in Early Childhood Education for Sustainability: International perspectives and provocations. Hoboken, NJ: Taylor and Francis.

Denzin, N. K., \& Lincoln, Y. S. (2011). The SAGE handbook of qualitative research. Los Angeles, CA: Sage.

Duhn, I. (2012). Making 'place' for ecological sustainability in early childhood education. Environmental Education Research, 18(1), 19-29.

Earth Charter Initiative. (2012). Earth Charter Initiative. Retrieved April 7, 2018, from http://earthcharter.org

Edwards, S., \& Cutter-Mackenzie, A. (2013). Pedagogical play types: What do they suggest for learning about sustainability in early childhood education? International Journal of Early Childhood, 45(3), 327-346.

Elliott, S. (2016). Provocations for the "next big thing" in early childhood education for sustainability (ECEfs). The International Journal of Early Childhood Environmental Education, 4(1), 3-9.

Elliott, S. (2017). An Australian perspective: Seeking sustainability in early childhood outdoor play spaces. In T. Waller, E. Arlemalm-Hagser, E. B. H. Sandseter, L. Lee-Hammond, K. Lekies, \& S. Wyver (Eds.), The Sage handbook of outdoor play and learning (pp. 295-316). London, UK: Sage.

Elliott, S. (2019, May 1). Education for sustainability [Blog Post]. Retrieved from http://thespoke. earlychildhoodaustralia.org.au/education-for-sustainability/

Elliott, S., \& Davis, J. (2009). Exploring the resistance: An Australian perspective on educating for sustainability in early childhood. International Journal of Early Childhood, 41(2), 65-77.

Elliott, S., \& Young, T. (2015). Nature by default in early childhood education for sustainability. Australian Journal of Environmental Education, 32(1), 57-64.

Engdahl, I., \& Ärlemalm-Hagsér, E. (2014). Education for sustainability in Swedish preschools. Stepping forward or out-of-step? In J. Davis \& S. Elliott (Eds.), Research in early childhood education for sustainability: International perspectives and provocations (pp. 208-224). New York: Routledge.

Ernst, J. (2015). Research in early childhood education for sustainability: International perspectives and provocations (book review). Children, Youth \& Environments, 25(1), 162.

Gothenburg Environment Centre. (2010). Taking Children seriously. How EU can invest in early childhood education for a sustainable future (No. 4). Gothenburg, Sweden: EPSD - European Panel on Sustainable Development.

Hackett, A. \& Rautio, P. (2019) Answering the world: young children's running and rolling as morethan-human multimodal meaning making, International Journal of Qualitative Studies in Education, 32(8), 1019-1031. DOI: 10.1080/09518398.2019.1635282

Harwood, D., \& Collier, D. (2019). Talk into my GoPro, I’m making a movie!” Using digital ethnographic methods to explore children's sociomaterial experiences in the woods (pp. 49-61). In Kucirkova, N., Rowsell, J., \& Fallon, G. (Eds.), The Routledge International Handbook of Learning with Technology in Early Childhood. London, UK: Routledge.

Harwood, D., \& Collier, D. (2017). The matter of the stick: Storying/re-storying children's literacies in the Forest. JECL special issue: Early Literacy and the Posthuman: Pedagogies and Methodologies, 17(3), 336-352. DOI: 1468798417712340

Haraway, D. (2008). When Species Meet. Minneapolis, MN: University of Minnesota Press.

Haraway, D., Ishikawa, N., Gilbert, S., Olwig, K. R., Tsing, A. L., \& Bubandt. N. (2015). Anthropologists are talking - about the Anthropocene." Ethnos 81 (3): 535-564.

Heise, U. K. (2016). The environmental humanities and the futures of the human. New German Critique, 43(128), 21.

Holbrook, J. (2009). Meeting challenges to sustainable development through science and technology education. Science Education International, 2O(1), 44-59. 
Holland, S., Renold, E., Ross, N. J., \& Hillman, A. (2010). Power, agency and participatory agendas: A critical exploration of young people's engagement in participative qualitative research. Childhood: A Global Journal of Child Research, 17(3), 360-375.

Hultman, K., \& Lenz Taguchi, H. (2010). Challenging anthropocentric analysis of visual data: A relational materialist methodological approach to educational research. International Journal of Qualitative Studies in Education (QSE), 23(5), 525-542.

Ingold, T. (2013). Making. Anthropology, archaeology, art and architecture. London, UK: Routledge

Inoue, M., O'Gorman, L., Davis, J., \& Ji, O. (2017). An international comparison of early childhood educators' understandings and practices in education for sustainability in Japan, Australia, and Korea. International Journal of Early Childhood, 49(3), 353-373.

Instone, L., \& Taylor, A. (2015). Thinking about inheritance through the figure of Anthropocene, from the antipodes and in the presence of others. Environmental Humanities, 7, 133-150.

Latour, B. (2004). Politics of nature: How to bring the sciences into democracy. Cambridge, MA: Harvard University Press.

Leather, M. (2018). A critique of "Forest School" or something lost in translation. Journal of Outdoor and Environmental Education, 1, 2-12.

LeCompte, M. D., \& Preissle, J. (1993). Ethnography and qualitative design in educational research. San Diego, CA: Academic Press.

Lewis, S. L., \& Maslin, M. A. (2015). Defining the Anthropocene. Nature, 519, 171-180.

Lynch, J., \& Mannion, G. (2016). Enacting a place-responsive research methodology: Walking interviews with educators. Journal of Adventure Education and Outdoor Learning, 16(4), 330-345.

Mackey, G. (2012). To know, to decide, to act: the young child's right to participate in action for the environment. Environmental Education Research, 18(4), 473-484.

Malone, K. (2016). Reconsidering children's encounters with nature and place using posthumanism. Australian Journal of Environmental Education, 32(1), 42-56. https://doi.org/10.1017/ aee.2015.48

Ministry of Education New Zealand. (2015). Education for sustainability. Retrieved from http:// nzcurriculum.tki.org.nz/Curriculum-resources/Education-for-sustainability/AboutEfS\#collapsible1

Mitchell, C. (2011). Doing visual research. Los Angeles, CA: SAGE.

Neil, D. (2007). The 50 worst cars of all time. Time Magazine. Retrieved from http://time.com/ time/specials/2007/article/o,28804,1658545_1657867_1657681,oo.html

Noddings, N. (2005). Educating citizens for global awareness. New York, NY: Teachers College Press.

Nxumalo, F. (2018). Stories for living on a damaged planet: Environmental education in a preschool classroom. Journal of Early Childhood Research, 16(2), 148-159.

Nxumalo, F., \& Cedillo, S. (2017). Decolonizing place in early childhood studies: Thinking with Indigenous onto-epistemologies and Black feminist geographies. Global Studies of Childhood, 7(2), 99.

Pacini-Ketchabaw, V. (2013). Frictions in forest pedagogies: Common worlds in settler colonial spaces. Global Studies of Childhood, 3(4), 355.

Pineda, M. (2018). Mama spider. Journal of Childhood Studies, 43(1), 73-80.

Pink, S. (2001). Doing visual ethnography: Images, media and representation in research. London, UK: Sage.

Pink, S. (2015). Doing sensory ethnography (2 $2^{\text {nd }}$ Edition). London, UK: Sage.

Plumwood, V. (2002). Environmental culture: The ecological crisis of reasoning. New York, NY: Routledge.

Pramling Samuelsson, I. (2011). Why we should begin early with ESD: The role of early childhood education. International Journal of Early Childhood, 43(2), 103-118. 
Pramling Samuelsson, I., \& Park, E. (2017). How to educate children for sustainable learning and for a sustainable world. International Journal of Early Childhood, 49(3), 273-285.

Rautio, P. (2013). Children who carry stones in their pockets: On autotelic material practices in everyday life. Children's Geographies, 11, 394-408.

Ritchie, J., Duhn, I., Rau, C., \& Alberts, J. K. (2010). Titiro whakamuri, hoki whakamua - Caring for self, other and the environment in early years' teaching and learning. Wellington, NZ: TLRI/New Zealand Council for Educational Research. Retrieved from http://www.tlri.org.nz/ sites/default/files/projects/TLRI-Ritchie-et-al-summary_1.pdf

Ritchie, J. (2017). Fostering eco-cultural literacies for social, cultural and ecological justice: A perspective from Aotearoa (New Zealand). International Journal of Early Childhood, 49(3), 287-302.

Roberts, A. (2007). Classic cars: Renault Dauphine. The Independent. Retrieved from https://www. independent.co.uk/extras/cars/classic-cars-renault-dauphine-396265.html

Robinson, L., \& Vaealiki, S. (2010). Ethics and pedagogy at the heart of early childhood education for sustainability. In J. Davis (Ed.), Young children and the environment: Early education for sustainability (pp. 103-123). Melbourne: Cambridge University Press.

Rooney, T. (2018). Weather worlding: learning with the elements in early childhood. Environmental Education Research, 24(1), 1-12.

Rose, G. (2012). Visual methodologies: An introduction to researching with visual materials. Thousand Oaks, CA: Sage.

Somerville, M. (2017). Thinking critically with children of the Anthropocene (un)learning the subject in qualitative and postqualitative inquiry. International Review of Qualitative Research, 10(4), 395-410. doi: 10.1525/irqr.2017.10.4.395.

Somerville, M., \& Williams, C. (2015). Sustainability education in early childhood: An updated review of research in the field. Contemporary Issues in Early Childhood, 16(2), 102-117.

Stake, R. E. (2008). Case studies. In N. K. Denzin \& Y. S. Lincoln (Eds.), Strategies of qualitative inquiry (3rd ed., pp. 134-164). Thousand Oaks, CA: Sage Publications.

Taylor, A., \& Giugni, M. (2012). Common Worlds: Reconceptualising Inclusion in Early Childhood Communities. Contemporary Issues in Early Childhood, 13(2), 108-119.

Taylor, A., \& Pacini-Ketchabaw, V. (2015). Learning with children, ants, and worms in the Anthropocene: Towards a common world pedagogy of multispecies vulnerability. Pedagogy, Culture \& Society, 23(4), 507-529.

Thiel, J. J. (2015). Vibrant matter: The intra-active role of objects in the construction of young children's literacies. Literacy Research: Theory, Method, and Practice, 64, 112-131. https://doi. org/10.1177/2381336915617618

Tsing, A. L. (2015). The mushroom at the end of the world: On the possibility of life in capitalist ruins. Princeton, NJ: Princeton University Press.

UNESCO. (2007). The UN decade of education for sustainable development, 2005-2014. Paris, FR: UNESCO. Retrieved from http://unesdoc.unesco.org/images/o015/001540/154093e.pdf

UNICEF. (2014). Children and climate change in Zimbabwe. UNICEF and Institute of Environmental Studies.

Vaealiki, S., \& Mackey, G. (2008). Ripples of action: Strengthening environmental competency in an early childhood centre. Early Childhood Folio, 12, 7-11.

Vladimirova, A., \& Rautio, P. (2018). Unplanning research with a curious practice methodology: Emergence of childrenforest in the context of Finland. In Cutter-Mackenzie A., Malone K., Barratt Hacking E. (Eds), Research Handbook on Childhoodnature (e-version, pp. 1-26). Springer International Handbooks of Education. New York, NY.

Wattchow, B., \& Brown, M. (2011). A pedagogy of place: Outdoor education for a changing world. Clayton, AU: Monash University Publications. 